AL IBTIDA: JURNAL PENDIDIKAN GURU MI (2020) Vol 7 (2) : 250-263

DOI: http://dx.doi.org/10.24235/al.ibtida.snj.v7i2.6817

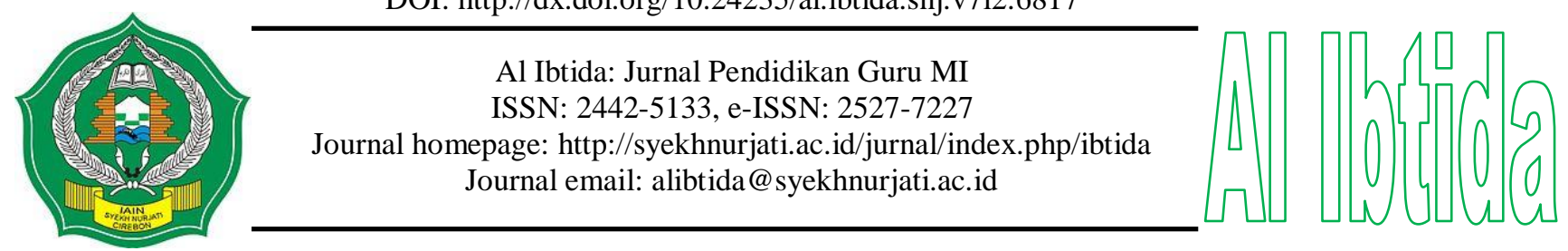

\title{
The Effect of Communication and Policy-Making to Teacher's Performance on Strategic Madrasah Leadership during Pandemic Covid-19
}

\author{
Ahmadi* \\ *Department of Islamic Education, Faculty of Tarbiyah and Teacher Training, \\ Institut Agama Islam Negeri Ponorogo, Indonesia \\ Email: ahmadi@iainponorogo.ac.id \\ Ahmad Romadlon** \\ **Madrasah Ibtidaiyah Al-Islam Madiun, Indonesia. \\ Email: romadlonahmad62@gmail.com
}

Received: July 19 ${ }^{\text {st }}, 2020$. Accepted: October 06 $6^{\text {th }}, 2020$. Published: October $30^{\text {th }}, 2020$.

\begin{abstract}
Communication and policy making can either increase or decrease performances. This study aims to measure whether communication and policy making have impacts on teachers' performance. This research is a quantitative study using proportional random sampling technique. The research data were obtained through a questionnaire and were then analyzed by the t-test and multiple linear regression analysis. The research results showed that both communication and policy-making styles had a significant impact on teachers' performance, and simultaneously the communication style and policy-making style had an impact on teacher performance by $71.1 \%$. Thus, the strategic leadership of madrasa principals at the Islamic Elementary School level should be taken into account to formulate differentiation and diversification strategies of communication policies, especially during the Covid-19 pandemic.
\end{abstract}

Keywords: assessment, communication skills, elementary school students.

\begin{abstract}
Abstrak
Komunikasi dan pengambilan kebijakan dapat meningkatkan kinerja atau sebaliknya. Penelitian ini bertujuan untuk mengukur apakah hal tersebut berdampak terhadap kinerja guru. Penelitian ini merupakan penelitian kuantitatif dengan teknik pengambilan sampel menggunakan proportional random sampling. Data hasil penelitian diperoleh melalui kuesioner dan dianalisis dengan rumus uji t-tests dan analisis regresi linier berganda. Hasil penelitian menunjukkan bahwa gaya komunikasi secara signifikan berdampak terhadap kinerja guru, gaya pengambilan kebijakan secara signifikan berdampak terhadap kinerja guru, dan secara simultan gaya komunikasi dan gaya pengambilan kebijakan berdampak terhadap kinerja guru sebesar $71.1 \%$. Sehingga, kepemimpinan kepala madrasah yang strategik di tingkat pendidikan dasar Islam seharusnya dipandang untuk memformulasikan strategi diferensiasi dan diversifikasi pada kebijakan komunikasi lebih lanjut, apalagi pada masa pandemi Covid-19.
\end{abstract}

Kata kunci: penilaian, kemampuan komunikasi, siswa sekolah dasar. 


\section{INTRODUCTION}

At the end of 2019, the dangerous virus first began to spread in Wuhan, China. This outbreak has disrupted all aspects in life. Governments all over the world have applied several policies to overcome this pandemic as effectively as possible. The Covid-19 pandemic has forced changes in various aspects of life (Irawan, 2020). Prospective scenarios to overcome a massive pandemic had been prepared before but most people weren't aware of it, such as the case in the MERS scenario. It offered important opportunities for readers to prepare their responses to express their dilemmas (Brunson et al., 2020). The current crisis situation may leave employers with no choice but to lay off because they have to reduce large-scale operation costs (Mahammed, 2020).

The social force needs a good communication, policy style, and strategic leadership in education. This indicates the need for a basic motivation for making successful and accountable decision (Geisler \& Allwood, 2018). Information sharing is expected to create balances among communication, decision-making, and teacher's performance, all of which are included in headmaster's performance (Sihotang, 2012). There are also positive and significant influences of teachers who have passed teacher's professional standard and those who haven't on students' learning achievement at elementary schools in Sambas-Indonesia (Putra, 2017).

It is then assumed that the implementation of knowledge based strategy needs human resources with knowledge and multiple skills in responding to permanent changes (Akhyak, 2013). Teacher's Performance will increase along with healthy relationships and communication between the components of the school because the pattern of relationships are smooth communication and good encouragement to do a good job (Saondi \& Suherman, 2010). The state of product sharing of information or communication is better continued to a sequences of main idea in paragraph, otherwise till to the art of communications (Villar et al., 2018). The Implementation of policy and commitment of existing leader can be measured and in the future it can be even better (Muldiyanto, 2019).

The ability of school principals in institutional decision-making has an implication to a standard of managerial competence. School principals should be able to manage the school information system in order to support the programs and policy in their institutions. He should seek a solution to gain a madrasah education of quality, so all components from various elements support each other i.e., a total quality of professional teachers, a synergy partnership between the madrasah committee with its management system to find out a learning organization climate by working together to gain vision and mission of the madrasah (Iswan, 
2015). A principal receives some in service-training on a modern management system approaches. This is considered to be able to enhance the ability of his meta literary so far to face a community preference (Gupta, 2020).

Important decisions for the survival of an organization encompass: i) decision is the beginning of all conscious responds focused on human activities, either individually, in group or institutionally, ii) it's intended to predict future outcomes, iii) it creates problems and solutions (Hasibuan, 2014). The decision process requires the involvement of various internal and external agencies. The Principals with the board of teachers, educational staff, students, and guardians are internal parties, while stakeholders are external party of educational institutions (Torang, 2013). There are numerous strategies at various level (i.e. individual, classroom, and school) that can be implemented to help students cope with a variety of stressors. Educators of students with stress and/or trauma need to be aware of its impact on children, and the most effective ways to address their education and social needs. Having practical strategies to assist students is essential in creating a caring community within the school (Keown et al., 2020). It is suggested from the findings that primary school students and teachers want to improve the same basic issues related to a peaceful and happy school (Calp, 2020).

Teacher's performance can be measured by several aspects such as work's quality, personal attitudes and responsibility for their work. Thus, teachers should develop their professionalism by: i) mastering knowledge and enhancing technology, ii) understanding education institution's needs, iii) meeting the demands of the world of work, facing the global competition, avoiding teachers' low professionalism, and iv) improving self-esteem (Muyiman, 2018).

Considerable research have been conducted on closed relationship with the world of policy-making in education, whose are expected to communicate well in their institutions. Such as; communication is the core of the organization, without it there will be no organizational activity (Ismail,2013). The principal should upgrade the supervision of teachers and achievement motivation where they would actualize the effective teachers (Renata et al., 2018). There has not been seen any influence between principal's leadership and the students' achievement level (Hadi, 2019). The madrasah would have been better if the principle's leadership practices put on the core of character and their beliefs in Islam for development and changes (Walid, 2018). The educational policy-makers were able to improve educator's loyalty by implementing a good program of instructor's standardization regulated professionally drives to government employee at regional era (Werang, 2018). Islamic 
education administrators should be managed using a strategic planning instead of their own group, tribes, and belief, so there is a compass for improving gradually furthermore.(Mahmud, 2012). Otherwise, the research about communication, policymaking, and teacher's performance during pandemic-19 hasn't been conducted yet, they should do it.

During 2020, the President of Republic of Indonesia and most of Indonesia's Ministers have made several policies to overcome social problems caused by Covid-19; ICT revolution, radicalism, learning based internet, and work from home, but there have not been any effective solutions yet. It's necessary to understand comprehensively their surrounding changes for making an appropriate decision-making. Furthermore, most of teachers, students, parents, and headmaster are confused to look forward their responsibility in education anymore, such as education policy-making related to distance learning, character, vocational skills, and reducing some materials. The blueprint hasn't been introduced yet, so these will be blunder of communication and policy-making at education level. The principals are struggling to overcome stress caused by pandemic-19; positive attitude towards self and others, effective management of time, delegation of duties to the staff, seeking support from other school stakeholders, sharing a meal with the family, socializing with the staff members, anger management, leisure activities, spending time with students, seeking medical help, seeking counseling, documenting files, and physical exercises (Ogalo et al., 2020).

This research aims to measure the strategic relationship in communication style, decision, and teacher's performance conducted by the headmaster. Because of the changes of situation of learning milieu such as social changes, family type, cross-culture, politics, and preference have happened rapidly, the act of leadership's alignment is necessary to be considered in policy decision making.

\section{METHODS}

The researchers applied a quantitative research design. In this case, both communication and decision making styles are independent variables while teachers' performance is the dependent variable. It was interesting to measure all of them partially and simultaneously and to predict what effects the two independent variables on dependent one. This is the design of the research: 


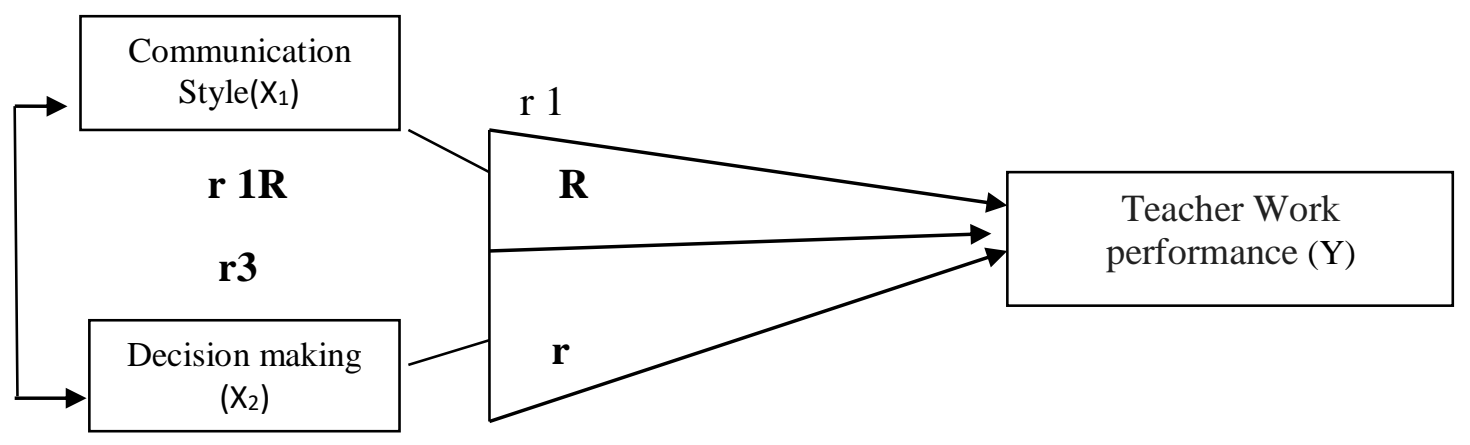

Figure 1. Research Design Scheme

We took population and sample at Islamic elementary school (MI) located at Madiun City. The reason why they chose Islamic elementary school to be the object was because of policy selection. The Madrasah is a good system for formal education like modern school system, but not sufficient to inculcate Islamic value outside the class (Zarkasyi, 2020).

Researchers used a propositional random sampling technique to determine the Madrasah which is a study sample by region or cluster one. They grouped them based on dormitory classes of their residences. The ratio between the numbers of teachers and students is $1 / 15$ meaning that a teacher for 15 students. It could be described as follows:

Table 1: Closter of Population

\begin{tabular}{llllll}
\hline No & Sub-District & School & Student & teacher & ratio \\
\hline 1 & Kartoharjo & 2 & 414 & 28 & 15.24 \\
2 & Taman & 5 & 3295 & 201 & 16.39 \\
3 & Mangunharjo & 2 & 414 & 28 & 14.79 \\
\hline
\end{tabular}

The Manister of Religion Affair at Madiun City, Indonesia. 2017

The researchers constructed questionnaires based on the research matrix, developed so far from the theories of communication, policymaking, and teacher's performance. Those are; i) Communication style indicators; controlling, equalitarian, structuring, dynamic, relinquishing, and withdrawal, ii) Policymaking style indicators; directive, analytic, conceptual, and behavior ones, iii) Teacher's performance indicators; loyalty, recognition, honesty, discipline, creativity, team working, leadership, personality, manipulation, and responsible. The questionnaires were 60 items that consist of 16 for communication style, 20 for policymaking style, and 24 for teacher's variables. A Likert Scale was chosen in constructing them which have been clarified by expert judgment so far.

Every respondent had the same opportunity to answer, so the researchers distributed them by accident while meeting everywhere happened accurately. After that, the data analyzed by t-test formula and multiple linear regression analysis using Statistical Package for the Social Sciences (SPSS) 2017 version. 


\section{RESULTS AND DISCUSSION}

The responses related to the communication style indicated that the respondent's answer has the lowest average score of 2.6358 which is associated with the statement that the head of the madrasah at work meetings. The highest score of 4.7514 is related to the respondent's statement that the head of the madrasah is attentive with supportive style trait.

In the decision-making style based on the SWOT, it showed that the respondent's answer has the lowest average score of 3.1098 which is related to the assertion of the madrasah takes a relatively quick decision. Fast decision-making is assumed to have unmeasurable and unpredictable decision. The highest score of 4.5491 is related to the respondent's statement that the principal decides systematically. It shows the decision-making style of the madrasah principal tend to have behavioral communication style. A leader's mindset must influence strategic decision making because of its structure (Phipps, 2012). The benefits of policymaking, as key factors, makes instructors be able to improve their performances perfectly, so students must be happy(Carver-Thomas \& Darling-Hammond, 2019). Everyone in organization have an opportunity as participants in decision-making (Villar et al., 2018).

Respondents stated that the teachers' work performance variables showed the highest score of 4.4682 which is related to the respondent's statement due to receiving additional task from the leadership. This statement refers to the sub-variables of work performance regarding the responsibility of teachers in implementing the management decisions. The respondents' answers about work performance showed an average total score of 3.7475; this shows that the performance of the Madrasah Ibtidaiyah teachers at Madiun city is so good. The factors of performance appraisal are; i) loyalty; ii) achievements; iii) honesty, iv) discipline, v) creativity, vi) cooperation, vii) leadership, viii) personality, $x$ ) and responsibility (Hasibuan, 2014).

The questionnaire data tabulated and analyzed using multiple linear regression as below:

Table 2. Analysis of Multiple Regression

\begin{tabular}{|c|c|c|c|c|c|c|}
\hline \multicolumn{7}{|c|}{ Coefficients $^{\mathbf{a}}$} \\
\hline & \multirow{2}{*}{ Model } & \multicolumn{2}{|c|}{$\begin{array}{l}\text { Unstandardized } \\
\text { Coefficients }\end{array}$} & \multirow{2}{*}{$\begin{array}{c}\text { Standardized } \\
\text { Coefficients } \\
\text { Beta }\end{array}$} & \multirow{2}{*}{$\mathrm{T}$} & \multirow{2}{*}{ Sig } \\
\hline & & B & Std. Error & & & \\
\hline \multirow[t]{3}{*}{1} & (Constant) & -6.171 & 4.854 & & -1.271 & .205 \\
\hline & Communication style & .188 & .080 & .123 & 2.349 & .020 \\
\hline & $\begin{array}{l}\text { decision-making } \\
\text { style }\end{array}$ & 1.027 & .071 & .762 & 14.559 & .000 \\
\hline
\end{tabular}

a. Dependent Variable: teacher work achievement 
From the table 2, it can be explained as follows: $\mathrm{Y}=-6,171+0,188 \mathrm{X} 1+1,027 \mathrm{X} 2$, It means; fisrt; $\mathrm{a}=-6,171$; which shows the magnitude of teacher work performance before influenced by communication style and decision-making style, second; b1=0.188; communication style variables have an effect of 0.188 to improve teacher work performance, thirst; $\mathrm{b} 2=1,027$; the decision-making style variable has an effect of 1.027 to raise ones. The result can be presented that decision-making style variable has a greater influence in increasing the performance of teachers compared with the communication style variables.

Result of partial test of influence of communication style on teacher work achievement of MI shows that the result of $\mathrm{t}$-test value is 2,349 and $\mathrm{t}$-table is 1,974 then ( $\mathrm{t}$ count $>\mathrm{t}$-table). Then from the significant level of 0.020 is smaller. Therefore, H0 is rejected and $\mathrm{H} 1$ is accepted. This means that for partial communication style variable has a significant effect on teacher's performance when the headmaster applies a style of communication that is a supportive style trait (supportive style trait). In other words, if the communication style of the madrasah principal goes well then the teachers work achievement is also increasing. Conversely, if the communication style does not work well then the teacher's work performance will also decrease. Enhancement for ability in communication produced some advantages which gave a temporary needs and preferences. It made a adaptable and cohesion change (Todorović et al., 2012).

A Partial test of effect of decision making style on teacher work's performance shows that the result of $\mathrm{t}$-count value is 14,559 and $\mathrm{t}$ - table is 1,974 (tcount $>\mathrm{t}$-table). Then from a significant level of 0.000 less than $0.05(0,000<0.05)$. Therefore, H0 is rejected and H1 is accepted. Decision style variable partially has a positive influence on teacher's work performance, when the head of the madrasah applies behavioral decision-making style. In other words, if the madrasah principal decision-making style is supportive of the behavioral style, then the teacher's work performance also increases. Conversely, if the decision-making style of the madrasah does not support or decrease, the teacher's work performance will decrease also.

Data analysis of influence of communication style and decision making of the madrasah headmaster on teacher's work performance at MI Madiun City. (Simultan Test/ fTest). 
Table 3. The Result of F Test

\begin{tabular}{lcccccc}
\hline \multicolumn{8}{c}{ ANOVA $^{\mathbf{a}}$} \\
Model & Sum of Squares & Df & Mean Square & F & Sig. \\
\hline 1 & Regression & 13570.332 & 2 & 6785.166 & 209.301 & $.000^{\mathrm{b}}$ \\
Residual & 5511.090 & 170 & 32.418 & & \\
Total & 19081.422 & 172 & & & \\
a. Dependent Variable: Teacher Work Achievement \\
b. Predictors: (Constant), Decision Making Style, Communication Style.
\end{tabular}

The result of $F$ test explained the magnitude of f-count: 209.301 and f-tabel: 3.05 ; means f-arithmetic $>$ f-table at $5 \%$ error rate, significant magnitude (profitability) $0,000<0.05$ $(\alpha=5 \%)$. In conclusion, the communication style and decision-making style together influence the teacher's work performance. Analysis of determination coefficient $\left(\mathrm{R}^{2}\right)$

Table 4. Analysis of determination coefficient

\begin{tabular}{|c|c|c|c|c|}
\hline Model & $\mathrm{R}$ & R Square & $\begin{array}{l}\text { Model Summary } \\
\text { Adjusted R Square }\end{array}$ & Std. Error of the Estimate \\
\hline 1 & $.843^{\mathrm{a}}$ & .711 & .708 & 5.69370 \\
\hline
\end{tabular}

Table 4 showed the analysis of determination coefficient (R2) of 0.711 meaning that the change of work performance of teachers can be explained by the change of communication style variable and decision-making style together which account for $71.1 \%$. While the rest that is equal to $28.9 \%$ influenced by other variables outside. There are seven characters that are considered i) supporting, ii) developing, iii) giving recognition, iv) balancing reward and punishment, v) managing conflict, vi) having a teamwork, vii) and networking (Muhith, 2013).

Partial communication style variable has a significant influence on teacher work performances. Based on the responses related to the communication style, it shows that the respondent's answer has the lowest average score which is related to the statement that the headmaster of the madrasah at work meeting likes to get emotional. It can be said that the teachers are not happy when the headmaster of the madrasah when he is applying emotional communication style (Emotive style trait). The highest score related to the respondent's statement indicated that the headmaster of the madrasah is attentive to others. It can be said that the teachers are happy when the headmaster of Islamic school apply supportive style trait (a supportive style trait). Furthermore, the total score average of 4.0725 , which indicates that the supportive communication style is able to influence the performance of work better or increase than other communication styles. Teacher were generally positive about the content 
and relevance of academic curriculum and its effectiveness in preparing them to teach reading (Gupta \& Lee, 2020). Strategic communication represented at multiple levels within and by the organization (Henderson et al., 2015).

Communication should be a something that people get a structure of knowledge, information, a system of context, and various consequences (Mbirua, 2020). It needs processing information in a series based on the social, economic and political changes. With logical, rational, intuitive, and creative mindset, the headmaster can conduct strategic acts that can make a valuable policy and decision. Therefore, he should apply them as effectively as possible. In this case, the headmaster should adopt forms of communication to suit every occasion to avoid interruption. Headmaster should adopt feedback mechanism which guarantees efficiency and prudence in school management (Brunson et al., 2020).

The decision-making style should be developed based on the madrasah strategic planning drives to the quality of the madrasah leadership. This leadership can affect the work performance of an individual executive work as a form of responsibility to implement work decisions of the leadership, but performance is to have values in a matter from what has been done and so on. Somebody hast to measure himself if he want to treat others (Arifin, 2016). Work is an activity that does something. Otherwise, performance is the product of work achieved by employee while conducting tasks assigned to him. The way he thinks is the logical and rational mindset; processing information in a series, intuitively and creatively understanding something as a whole (Rivai \& Mulyadi, 2009).

The results of the research for decision-making style variables are smaller. This means that decision style variable partially have affected on teacher's performance. It shows the respondent's answer is the lowest average score which is related to the assertion that the head of the madrasah makes relatively quick decisions. Quick decision-making is assumed to result in am unmeasurable decision. It can be said that the teachers are not happy when the head of the madrasa apply a directive style of decision (directive style). For the highest score which is related to the respondent's statement that the head of the madrasah decides systematically. It can be said that the teachers are happy when the head of the madrasa applies a behavioral decision style (Behavioral Style) with an average score of 4.0812; this suggests that the teacher's decision-making style is better or improved.

For the effect of simultaneously showing that the communication style variables, and decision-making style together influence the teacher's work performance. For the change of work performance of the teacher can be explained by the change of communication style variable and decision-making style together equal to. It shows that there is still another 
variable to be investigated by further research. It can be concluded that the performance of the madrasah may turn positive or improve better when the head of the madrasah implements a supportive style trait style and sets a work decision with a behavioral style (Behavioral style trait). Conversely, work performance will decrease when the head of the madrasah applies an emotional style trait (Emotive style trait) and defines a work decision with a directive style (Directive Style). With new version of mobile devices, it makes our lives available changes, innovative spiritual, interesting features, and amazing accessories are continually optimizing communication (Odabasi et al., 2019).

Three components must be considered in this case; i) A strategic plan work is a duty for chief executive organization constructed on futuristic issues of micro-macro to counter the disruptive era, ii) develop a curricula according to education customer's preference and interest, and iii) modify programs for giving a spiritual activities and analogical reasoning ability for facing ICT era (Musyaifudin \& Ahmadi, 2019). It's important for leader of madrasah, teachers, staff, students, and board of school to behave strategically in order to be meaningful for a sustainable learning organization, experience development, and institution itself. Vincent introduced that there are six characters that should be considered; i) looking forward continuously, ii) handling business, iii) using a business information as success key indicator, iv) understanding the big picture, v) considering a risk and taking the appropriate strategy, vi) and relating vision and mission with business strategy (Gaspersz, 2013).

A strategic leadership must be able to work in cooperation, participation of employee both vertically and horizontally within and outside the job. He also has the ability how to judge an employee's capability to lead, influence, and behave befitted a strong, respected, and authoritative leader. Therefore, implementing a good leadership style is a necessary factor (Abdulllah et al., 2018). In a strategic leadership, personality related to attitude, behavior, modesty, and cheeriness lead to impression of being fun, sympathetic, and reasonable appearance of the employee. The result of Teacher's performance evaluation can essentially be used to be a promotion and reward (Masnun, 2014). His teachers should be also more active, creative, communicative and effective in performing duties as a professional teacher. Assuming the increased quality of teacher competence, they will also increase teacher's performance.

Education is still a mean of enlightenment. Especially, Islamic education is completely structured and predictable, and has ability to provide a comprehensive picture of Islam expected by the public, government officials, the leader of higher education institutions, 
influences religious movements and public figures in the country and abroad (Abdullah, 2017).

In the disruptive era, especially during the Covid-19 pandemic, mastering knowledge and technology comprehensively is able to force a surrounding to be a knowledge community. These changes include the application of the work from home system, social distancing, restrictions on public transportation facilities, limited lockdowns that are currently being implemented by several local governments (Mahammed, 2020). The complicated structure of science requires an intellectual mindset to produce any kind of competitive education market share that can create meaningful values for school stakeholder. Especially about a change of place, time and opportunity, lean innovation used to create sustainable advantages in the social context (Akhyak, 2013). Thus, strategic madrasah leadership, especially at elementary school as basic human management policy so far (Jaelani, 2016), needs to behave a strategic planning, implementation, and evaluation in order to be an effective learning organization.

Other variables assumed influences to teachers' performance; i) physical as a thing based on the body's natural sense, such as insecurity or pleasure, ii) a sophisticated of environment system, likewise; politics in locally or globally, economics supply chain, and uncertainty future iii) a rational community creates a rational workers, a rational migrant, and smart pupil as its various consequences, v) practicality; a person who has meta confident assess his modify activities, vi) emotional as a thing based on feelings or attitudes, vii) interpersonal as a thing based on the influence of existing social network (Rivai \& Mulyadi, 2009).

\section{CONCLUSION}

Communication style significantly affects teacher's performance, decision-making one significant does either, and also both of them. There are still influenced by other variables. Therefore, alignment communication and decision making style are very important in a strategic madrasah leadership at Islamic elementary schools because of the expectation to construct a differential and diversification strategy. The researchers recommend that if a marketplace has been unpredictable changes because of politics, social, economics, pandemic, and technology revolution, they should apply an intellectual property strategy continuously. In this case, the key of instruments are core values, an innovation, and non-linear thinking. 


\section{REFERENCES}

Abdullah, M. A. (2017). Islamic Studies in Higher Education in Indonesia: Challenges, Impact and Prospects for the World Community. Al-Jami'ah: Journal of Islamic Studies, 55(2), $391-426$.

Abdulllah, S. A. C., Yussoff, M. M., \& Mustafa, H. (2018). The Relationship between Integrated Marketing Communication and Leadership Styles-In the Context of Malaysian Higher Education. Indonesian Journal Of Business And Economics, 1(1).

Akhyak, M. A. (2013). Lean Innovation for school program improvement. Ibnu Sina Institute UTM, 766-771.

Arifin, S. (2016). Islamic religious education and radicalism in Indonesia: Strategy of deradicalization through strengthening the living values education. Indonesian Journal, 6(1), 93-126.

Brunson, E. K., Chandler, H., Gronvall, G. K., Ravi, S., Sell, T. K., Shearer, M. P., \& SchochSpana, M. L. (2020). The SPARS Pandemic 2025-2028: A Futuristic Scenario to Facilitate Medical Countermeasure Communication. Journal of International Crisis and Risk Communication Research, 3(1), 4.

Calp, Ş. (2020). Peaceful and Happy Schools: How to Build Positive Learning Environments. Lnternational Electronic Journal of Elementary Education, 12(4), 311-320. https://doi.org/10.26822/iejee.2020459460

Carver-Thomas, D., \& Darling-Hammond, L. (2019). The trouble with teacher turnover: How teacher attrition affects students and schools. Education Policy Analysis Archives, 27, 36.

Gaspersz, V. (2013). All-in-one Integrated Total Quality Talent Management. Baranangsiang Bogor, Tri-Al-Bros Publishing, Januari.

Geisler, M., \& Allwood, C. M. (2018). Relating decision-making styles to social orientation and time approach. Journal of Behavioral Decision Making, 31(3), 415-429.

Gupta, A., \& Lee, G.-L. (2020). The Effects of a Site-based Teacher Professional Development Program on Student Learning. International Electronic Journal of Elementary Education, 12(5).

Hadi, M. (2019). The Principal's Effective Leadership in Elementary Education. Elementary: Jurnal Ilmiah Pendidikan Dasar, 5(2), 127-140.

Hasibuan, H. M. S. (2014). Manajemen, Dasar, Pengertian, dan Masalah. Bumi Aksara.

Henderson, A., Cheney, G., \& Weaver, C. K. (2015). The role of employee identification and organizational identity in strategic communication and organizational issues management about genetic modification. International Journal of Business Communication, 52(1), 12-41.

Irawan, I. (2020). YouTube Channel Development on Education: Virtual Learning Solution during the Covid-19 Pandemic. International Journal of Advanced Sciences and Technology, 29(4), 2469-2478. 
Ismail, N. (2013). Budaya Organisasi Kepemimpinan dan Kinerja: Proses Terbentuk, Tumbuh Kembang, Dinamika, dan Kinerja Organisasi. Kencana Prenadamedia Grup. Jakarta.

Iswan, I., I. (2015). The Role of Total Quality Management In Improving The Teacher's Performance.

Jaelani, A. (2016). Pendidikan Dasar Dalam Era Reformasi dan Otonomi. Al Ibtida: Jurnal Pendidikan Guru MI, 3(1).

Keown, S., Carroll, R., \& Raisor, J. (2020). Creating a Community of Caring within the School. International Electronic Journal of Elementary Education, 12(4), 401-404.

Mahammed, M. A. (2020). Analysis of Covid-19 Lockdown Policy Impact by The Goverment of The Country on The Economics Sector and Signing of Working Relationship.(LAYOFFS). International Journal of Law Reconstruction, 4(1), 44-54. https://doi.org/10.26532/ijlr.v4i1.10942

Mahmud, M. E. (2012). Motif Penyelenggaraan Pendidikan Islam dan Implikasinya pada Pola Manajemen dan Kepemimpinan. Dinamika Ilmu, 12(2).

Masnun. (2014). Strategi Peningkatan Kinerja Guru. Al Ibtida: Jurnal Pendidikan Guru MI, Vol.1.No.2.

Mbirua, W.M, Thinguri. R. and Kenei.R.K. (2020). Influence of Headteacher's Communication Planning Practices on Management Performance in Public Primary School in Thika West Sub-County, Kiambu County, Kenya. International Journal for Innovation Education and Research., Vol.8.No.6. 2020.218-229.

Muhith, A. (2013). Transformational leadership: Ilustrasi di bidang organisasi pendidikan. RajaGrafindo Persada.

Muldiyanto, T. (2019). The Effect of Policy Implementation and Leadership Commitment on The Success of Licensing Services. International Journal of Economics, Business and Accounting Research (IJEBAR), 3(02).

Musyaifudin, M., \& Ahmadi, A. (2019, Oktober). Englighmnet Strategy Leads To A Quality Learning At Islamic School In 4.0.Era. Proccedings of the 5th International Conference On Education In Muslim Society (ICEMS).

Muyiman, M. (2018). The strategy of Madrasa Ibtidaiya Principal in human resource development for increasing teachers' professional and academic competency. MUDARRISA: Jurnal Kajian Pendidikan Islam, 10(1), 127-147.

Odabasi, M. B., Uzunboylu, H., Popova, O. V., Kosarenko, N. N., \& Ishmuradova, I. I. (2019). Science Education and Mobile Learning: A Content Analysis Review of the Web of Science Database. International Journal of Emerging Technologies in Learning (IJET), 14(22), 4. https://doi.org/10.3991/ijet.v14i22.11744

Ogalo, S. A., Odera, F., \& Ogogo, C. (2020). Strategies Employed by Principals to Overcome Stress in Performance of their work in Secondary Schools in Kisumu County. 8(7), 16.

Phipps, K. A. (2012). Spirituality and strategic leadership: The influence of spiritual beliefs on strategic decision making. Journal of Business Ethics, 106(2), 177-189. 
Putra, P. (2017). Pengaruh Kinerja Guru Bersertifikasi dan Belum Bersertifikasi terhadap Prestasi Belajar Siswa di MIN se-Kabupaten Sambas. JMIE (Journal of Madrasah Ibtidaiyah Education), 1(1).

Renata, R., Wardiah, D., \& Kristiawan, M. (2018). The Influence of Headmaster's Supervision and Achievement Motivation on Effective Teachers. International Journal of Scientific \& Technology Research, 7(4), 44-49.

Rivai, V., \& Mulyadi, D. (2009). Kepemimpinan dan Perilaku Organisasi: Jakarta: Rajawali Pers.

Saondi, O., \& Suherman, A. (2010). Etika profesi keguruan. Bandung: PT Refika Aditama.

Sihotang, R. (2012). Hubungan Antara Komunikasi Dan Pengambilan Keputusan Dengan Kinerja Kepala Sekolah Dasar Negeri Di Wilayah Jakarta Timur. Jurnal Manajemen Pendidikan, 3(2).

Todorović, J., Matejević, M., \& Simić, I. (2012). Educational styles, communication and contentment of students with their families. Procedia-Social and Behavioral Sciences, 69, 899-906.

Torang, S. (2013). Organisasi dan manajemen. Bandung: Alfabeta.

Villar, E. G., Walger, C. D. S., Abib, G., Róglio, K. D. D., \& Stocker, F. (2018). Deciding: Decision-making as a social practice. International Journal of Management and Decision Making, 17(3), 279-298.

Walid, M. (2018). Nilai dan Keyakinan, Kreatifitas, dan Kepemimpinan Kepala Madrasah dalam Mengelola Madrasah Ibtidaiyah Negeri Malang 1 Kota Malang. Al Ibtida: Jurnal Pendidikan Guru MI, 5(1), 107-132.

Werang, B. R. (2018). Pengaruh Keterampilan Managerial Kepala Sekolah dan Iklim Sekolah Terhadap Komitmen Kerja Guru Sekolah Dasar Kristen di Kabupaten Boven Digoel. Al Ibtida: Jurnal Pendidikan Guru MI, 5(2), 159-174.

Zarkasyi, H. F. (2020). Imam Zarkasyi's Modernization of Pesantren in Indonesia (A Case Study of Darussalam Gontor). QIJIS (Qudus International Journal of Islamic Studies), $8(1), 161-200$. 